\title{
Drilling the Aptian-Albian of the Sergipe-Alagoas Basin, Brazil: paleobiogeographic and paleoceanographic studies in the South Atlantic
}

\author{
Gerson Fauth $^{1}$, Mauro Daniel Rodrigues Bruno ${ }^{1}$, Jorge Villegas-Martín ${ }^{1}$, Jairo Francisco Savian ${ }^{2}$, \\ Rodrigo do Monte Guerra ${ }^{1}$, Guilherme Krahl ${ }^{1}$, Francisco Henrique de Oliveira Lima ${ }^{3}$, \\ Oscar Strohschoen Jr. ${ }^{3}$, Raquel Gewehr de Mello ${ }^{2}$, Fernando Marcanth Lopes ${ }^{1}$, \\ Carolina Gonçalves Leandro ${ }^{2}$, and Eduardo da Silva Aguiar ${ }^{1}$ \\ ${ }^{1}$ itt Oceaneon - Instituto Tecnológico de Paleoceanografia e Mudanças Climáticas, Unisinos University, \\ Av. Unisinos, 950, São Leopoldo, RS, 93022-750, Brazil \\ ${ }^{2}$ Departamento de Geologia e Instituto de Geociências, Universidade Federal do Rio Grande do Sul, \\ Av. Bento Gonçalves, 9500, Porto Alegre, RS, 91501-970, Brazil \\ ${ }^{3}$ PETROBRAS/CENPES/PDEP/BPA, Av. Horácio Macedo, 950, Cidade Universitária, \\ Ilha do Fundão, Rio de Janeiro, RJ, 21941-915, Brazil
}

Correspondence: Gerson Fauth (gersonf@unisinos.br)

Received: 26 June 2020 - Revised: 12 March 2021 - Accepted: 22 March 2021 - Published: 26 April 2021

\begin{abstract}
The Aptian-Albian interval is characterized by significant paleoclimatic, paleoceanographic, and paleogeographic changes, which in turn affected the distribution and evolution of marine ecosystems. Despite the importance of such studies, there have been few correlations between Aptian-Albian sections of the Tethys Sea and those of the South Atlantic Ocean. This interval, including the Aptian-Albian transition, is preserved in the deposits of the Riachuelo Formation (Sergipe-Alagoas Basin, Brazil) located in the South Atlantic Ocean; therefore, this location was chosen for drilling four new cores. The goals of this paper are as follows: (1) to explain the drilling operation carried out in the deposits of the Riachuelo Formation and the methods used; (2) to present a brief lithostratigraphic characterization of the holes and the paleomagnetic data of core SER03; and (3) to describe the high potential of the cores recovered for additional investigation in the future. The lithostratigraphic units of the SER-01 core consist mainly of coarse- to fine-grained sandstone, shales, marls, and mudstones; the SER-02 core was excluded due to low recovery; the SER-03 core is mainly composed of fine-grained sediments (shale, marls, and packstone) and bears some ammonite shells; the lithology of core SER04 is mainly sandstones. Magnetic susceptibility values ( $\chi \mathrm{lf}$ and $\chi \mathrm{hf}$ ) and frequency-dependent susceptibility $(\chi \mathrm{fd})$ data suggest that the section is located within the Cretaceous Normal Superchron. Future studies on these cores integrating micropaleontological, paleoichnological, geochemical, stratigraphic, and paleomagnetic (e.g., relative intensity) data will allow for a better understanding of paleoceanographic and paleogeographic events related to the early evolution of the South Atlantic Ocean and how these events correlate to similar events in Tethyan sections.
\end{abstract}




\section{Introduction}

The Early Cretaceous was an important period in the history of the Earth, during which greenhouse conditions prevailed and oceanic gateways gradually opened, allowing for the wide dispersion of marine organisms. The Aptian-Albian interval is characterized by significant paleoclimatic, paleoceanographic, and paleogeographic changes. In addition, important perturbations in the global carbon cycle, the development of large igneous provinces (LIPs) such as the Kerguelen Plateau and Rajmahal Traps, and an increase of the global sea level have also been recognized (e.g., Leckie et al., 2002; Courtillot and Renne, 2003; Haq, 2014). These changes affected the distribution and evolution of marine ecosystems on a worldwide scale (e.g., Dias-Brito, 1987; Riccardi, 1991; Leckie et al., 2002; Browning and Watkins, 2008; Huber and Leckie, 2011; McAnena et al., 2013; Coccioni et al., 2014; Dummann et al., 2020). This interval contains multiple black shale horizons associated with oceanic anoxic events (OAEs) such as the Selli, 113/Jacob, Kilian, Urbino/Paquier, and Leenhardt events (e.g., Erbacher et al., 1999; Leckie et al., 2002; Browning and Watkins, 2008; Jenkyns, 2010; Coccioni et al., 2014; Sabatino et al., 2015, 2018; Bottini and Erba, 2018). In addition, the Aptian-Albian was one of the most recent prolonged periods of stable polarity in the magnetic field of the Earth, the so-called Cretaceous Normal Superchron (CNS), which occurred approximately from 121 to $83 \mathrm{Ma}$ (Helsley and Steiner, 1968; Gee and Kent, 2007; He et al., 2008). Although the CNS has been extensively studied by paleomagnetic methods (e.g., Tarduno, 1990; Tarduno et al., 2001; Cronin et al., 2001; Granot et al., 2007, 2012; Biggin et al., 2008; Linder and Gilder, 2011), there is no consensus on the nature of this event. The global boundary stratotype section and point (GSSP) for the base of the Albian Stage has been formally defined in the Col de Pré-Guittard section, Vocontian Basin (VB), France, which contains deposits from the Tethys Sea (Petrizzo et al., 2016; Kennedy et al., 2017).

Micropaleontological, geochemical, and paleomagnetic studies in the GSSP section, as well as in other important sections, led to the establishment of different criteria for the identification and correlation of the Aptian-Albian boundary around the world (e.g., Herrle et al., 2004; Satolli et al., 2008; Petrizzo et al., 2012; Coccioni et al., 2012, 2014; Sabatino et al., 2015, 2018; Kennedy et al., 2017). For many years, discussions regarding the Aptian-Albian boundary were complicated mainly by the difficulty in correlating different sections of the Tethys Sea using ammonite zonal schemes and planktonic fossil groups (e.g., Kennedy et al., 2000, 2014; Huber and Leckie, 2011; Petrizzo et al., 2012; Ogg et al., 2016). Studies correlating sections of the Tethys Sea with those of other oceans such as the South Atlantic Ocean are very rare.

The Sergipe-Alagoas Basin includes the most complete marine Cretaceous sequences among all South Atlantic basins (Bengtson, 1983; Bengtson et al., 2018). It is known for its economic importance (oil and gas) and the diversity of its Cretaceous fauna and flora. The Lower Cretaceous marine sequence contains well-preserved Aptian-Albian strata in the Riachuelo Formation deposits, which have been extensively investigated using stratigraphic, paleontological, and geochemical data (e.g., Beurlen, 1968; Cainelli et al., 1987; Koutsoukos et al., 1991a, b; Koutsoukos and Bengtson, 1993; Bengtson et al., 2018). Multidisciplinary studies have demonstrated that the marine sequences in the basin represent "type-sections" of the full opening of the Equatorial Atlantic Gateway, considered as the last continental link between South America and Africa (Koutsoukos et al., 1991b; Feijó, 1996; Arai, 2014). In recent years, some studies have used different multiproxies (ichnofossils, microfossils and macrofossils, and sedimentological, geochemical, and paleomagnetic data) to identify the paleoenvironmental and paleoceanographic changes that took place during the AptianAlbian interval in the South Atlantic (e.g., Koutsoukos et al., 1991a; Carvalho et al., 2016; Valle et al., 2019).

\section{Scientific objectives}

The most important objectives of drilling the SergipeAlagoas Basin are to understand the nature of the marine incursions during the Aptian-Albian interval and if there are possible correlations with paleoclimatic and paleoceanographic events on a global scale during this time interval (Fig. 1). It is also important to assess if a correlation exists between the biotic assemblages of the South Atlantic Ocean and Tethys Sea through a detailed study of a fresh, continuous drill core. These objectives will be pursued through (i) a detailed stratigraphy of the whole sections, (ii) organic and inorganic geochemistry of sedimentary rocks, (iii) study of microfossils, (iv) study of ichnofossils, (v) geochemistry (including stable isotopes) on microfossils, and (vi) paleomagnetic study on oriented core samples. Thus, from these data, we intend to evaluate three important questions about the Aptian-Albian interval, which are outlined in Sects. 2.1-2.3.

\subsection{What is the impact of the establishment of oceanic gateways during the Aptian-Albian interval?}

This is based on the composition of the microfossil (planktonic foraminifera, calcareous nannofossil, ostracods, palynology, and radiolarians) and macrofossil assemblages in the South Atlantic Ocean. These data could suggest a grade of provincialism or a direct relation with the biota assemblages identified in the Tethys Sea. During the Early Cretaceous, the physiographic barriers of the Rio Grande Rise-Walvis Ridge System (located in the southern region) and the Equatorial Atlantic Gateway (located in its northern region) may have restricted the development of a connection between the proto-South Atlantic and the surrounding oceans (Fig. 1), thereby interfering with the establishment of open marine conditions (e.g., Arthur and Natland, 1979; Rabinowitz and 

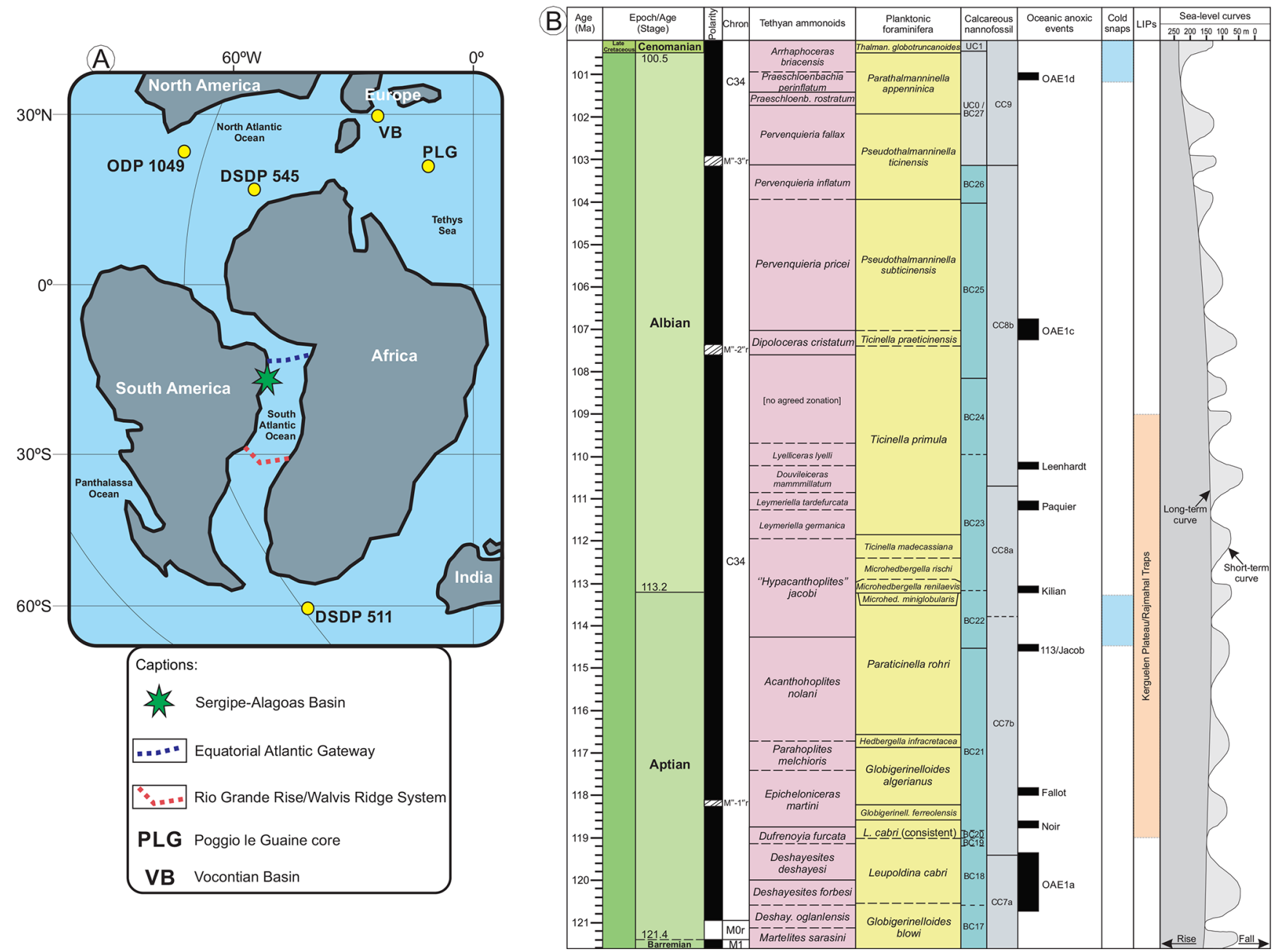

Figure 1. (a) Paleogeographic reconstruction at 112 Ma (modified after Hay et al., 1999) showing the location of the Sergipe-Alagoas Basin, the Equatorial Atlantic Gateway, the Rio Grande Rise-Walvis Ridge System, the Vocontian Basin (VB), the Poggio le Guaine (PLG) core, and the Deep Sea Drilling Project (DSDP) and Ocean Drilling Program (ODP) sites containing the Aptian-Albian boundary. (b) Stratigraphic chart of the drilled section with biostratigraphic zones for ammonoids, planktonic foraminifera, and calcareous nannofossil (Gale et al., 2020). For this interval, the main ocean anoxic events (Gale et al., 2020), cold snaps (Hu et al., 2012), large igneous provinces - LIPs (Courtillot and Renne, 2003), and sea level curves (Haq, 2014) are also shown.

Labrecque, 1979; Rand and Mabesoone, 1982; Sibuet et al., 1984; Dias-Brito, 1987; Azevedo, 2004; Torsvik et al., 2009; Arai, 2014; Silva et al., 2020).

During the late Aptian-Albian interval, the surface water connection between the South Atlantic and eastern Tethys (Central Atlantic segment) was fully formed, creating migration routes and physicochemical conditions in the water column that were ideal for the establishment of new marine biota (e.g., Dias-Brito, 1987; Riccardi, 1991; Feijó, 1996; Pérez-Díaz and Eagles, 2017). Fossil assemblages of the South Atlantic have shown a strong affinity to the Tethyan realm (e.g., Dias-Brito, 1987; Colin and Andreu, 1990; Koutsoukos, 1992; Arai, 2014; Silva et al., 2020; Bruno et al., 2020). However, South Atlantic ammonite fossils do not seem to show any affinity to the "Tethyan standard zonation"
(Bengtson et al., 2018). According to Michels et al. (2018), the South Atlantic Aptian-Albian palynologic assemblages show a high degree of provincialism as well, such as the Dicheiropollis etruscus/Afropollis Province, which can be observed in other marginal basins around Brazil and Africa and is mainly defined by a gymnosperm paleoflora strongly adapted to warm and dry local climate conditions.

\subsection{Do the South Atlantic Ocean deposits record the Aptian-Albian climatic variations?}

This is based on the capacity of an integrated analysis of the micropaleontological, ichnological, paleomagnetic, and stratigraphic data from the Riachuelo Formation for important paleoenvironments events in the South Atlantic Ocean 
during the Aptian-Albian interval, such as the supposed cooling events (cold snaps) and the two previously recorded evolutionary phases and biota disturbances (Mutterlose et al., 2009; Huber and Leckie, 2011; McAnena et al., 2013). McAnena et al. (2013) expressed that cold snaps during greenhouse conditions could cause perturbations in the marine biotas and biogeochemical cycles. Although greenhouse conditions are widely accepted for the Aptian-Albian interval on a global scale, some studies using geochemical and micropaleontological data indicate that short-lived cooling events (cold snaps) also occurred (e.g., Pirrie et al., 1995, 2004; Erbacher et al., 1999; Clarke and Jenkyns, 1999; Herrle and Mutterlose, 2003; Mutterlose et al., 2009; Huber and Leckie, 2011; Jenkyns et al., 2012; McAnena et al., 2013; Bottini et al., 2015; Herrle et al., 2015).

Studies based on stable oxygen isotope analyses in bulk marine carbonates and belemnites (e.g., Pirrie et al., 1995, 2004; Clarke and Jenkyns, 1999; Föllmi, 2012; Jenkyns et al., 2012), TEX 86 paleothermometry proxies (e.g., Jenkyns et al., 2012; McAnena et al., 2013; O'Brien et al., 2017), and calcareous nannofossil distributions (Herrle and Mutterlose, 2003; Mutterlose et al., 2009; Herrle et al., 2015; Bottini et al., 2015) have indicate a transition from a prolonged cooling period during the late Aptian to a significantly warmer period during the early Albian. Mutterlose et al. (2009) showed two possible cooling periods at low- and high-latitude sites using nannoplankton data in this interval. Both periods have been identified in the Northern and Southern hemispheres. Finally, Huber et al. (2011) correlated foraminifer biostratigraphy and chemostratigraphic data from the Aptian-Albian interval in the Blake Nose region (Ocean Drilling Program, ODP, sites 1049A and 1049C; Fig. 1), and they suggested cool sea surface temperatures and elevated salinity related to high evaporation rates, demonstrating a limited connection between the sedimentary basins of the proto-Atlantic Ocean (Central Atlantic Seaway or Tethys Sea).

\subsection{What are the prospects for a multidisciplinary correlation between the Tethys Sea and the Sergipe-Alagoas Basin?}

The idea is to integrate analyses of the micropaleontological, geochemical, and paleomagnetic data obtained from the Riachuelo Formation (Aptian-Albian interval, SergipeAlagoas Basin) to identify similar patterns and help clarify the relationship between the South Atlantic Ocean and the Tethys Sea, and to try identify the paleoclimatic, paleoceanographic, and evolutionary/distribution events of the marine biota in the Sergipe-Alagoas Basin as recorded in other Aptian-Albian reference sections (Vocontian Basin; Poggio le Guaine section, PLG; DSDP 511; DSDP 545; ODP 1049) (Fig. 1). In these sections, studies using micropaleontological and geochemical data as well as paleomagnetic signals have provided important information for the identification and characterization of the Aptian-Albian boundary and some paleoclimatic inferences such as the OAE1b. For example, the first occurrence (FO) of the planktonic foraminifera Microhedbergella renilaevis, the last occurrence (LO) of the planktonic foraminifera Paraticinella rohri (= Paraticinella eubejaouensis), the FO of the calcareous nannofossils Prediscosphaera columnata (circular forms) and Helicolithus trabeculatus, and the geochemical correlation event (minimum value of $1 \%$ negative $\delta^{13} \mathrm{C}$ excursion) have demarked the Aptian-Albian boundary in the global boundary stratotype section and point (GSSP) of the Col de Pré-Guittard section from the Marnes Bleues Formation, Vocontian Basin, France (Petrizzo et al., 2016; Kennedy et al., 2017).

In addition, the late Aptian-Albian interval has been characterized by an important time in the evolution of planktonic foraminifera including extinction and speciation events and changes in shell architecture (e.g., Leckie et al., 2002; Huber and Leckie, 2011; Petrizzo et al., 2012). Thus, late Aptian foraminiferal assemblages showed larger, heavily ornamented species, whereas the Albian foraminiferal assemblages comprise small-sized species in different deep-sea sites in the Atlantic and Indian oceans (Huber and Leckie, 2011). Coccioni et al. (2014) used geochemical proxies, planktonic foraminifera, and calcareous nannofossils assemblages to characterize the PLG section that can be used to correlate OAE1b black shale horizons between different marine environments. They also demonstrated that the PLG section can be correlated with the Aptian-Albian deposits of the Vocontian Basin (Fig. 1). Later, Sabatino et al. (2015) developed a chemostratigraphic study for the same sites studied by Coccioni et al. (2014), suggesting an increase in surface water productivity and a reduction in bottom water ventilation during the OAE1b. Other data available for correlation are the presence of an isotopic standard curve (Herrle et al., 2004) and the identification of a geomagnetic event Superchron C34-Cretaceous Quiet Zone (Ogg et al., 2016) for the Aptian-Albian interval.

\section{Geological background}

The Sergipe-Alagoas Basin was originally described as a single basin by Schaller (1969). However, later stratigraphic revisions divided it into two sub-basins, Sergipe and Alagoas (Feijó, 1994; Campos Neto et al., 2007). It is an elongate continental-margin basin located in northeastern Brazil $\left(9-11^{\circ} 30^{\prime} \mathrm{S}, 37-35^{\circ} 30^{\prime} \mathrm{W}\right)$, delimited by the PernambucoParaíba Basin to the northeast (Maragogi high) and the Jacuípe Basin (Jacuípe high) to the southwest (Fig. 2). The onshore and offshore sedimentary sequences of the SergipeAlagoas Basin reflect distinct tectono-sedimentary phases of the Brazilian Equatorial Continental Margin (BECM), prerift, rift, post-rift, and drift. The onshore portion covers an area of approximately $13000 \mathrm{~km}^{2}$, whereas its offshore portion is around $40000 \mathrm{~km}^{2}$ (Feijó, 1994; Mohriak, 2003; Campos Neto et al., 2007; Antonietto et al., 2015). The structural 
framework of the basin is characterized by large tilted fault blocks, forming structural highs and lows (e.g., Mohriak et al., 1998; Kellogg and Mohriak, 2001).

The stratigraphic evolution of the Sergipe-Alagoas Basin is similar to other South Atlantic marginal sedimentary basins, starting with continental sequences that gradually transition to marine ones (e.g., Asmus and Porto, 1972; Berggren and Hollister, 1974; Asmus, 1984; Kellogg and Mohriak, 2001; Milani et al., 2007; Mohriak et al., 2008; Mohriak and Fainstein, 2012). Sedimentary deposits related to the first marine incursions in the South Atlantic are characterized by extensive evaporitic and calcareous sequences developed during the Early Cretaceous, mainly characterized by sedimentary deposits of the Muribeca Formation (e.g., Asmus and Porto, 1972; Milani et al., 2007; Mohriak et al., 2008; Mohriak and Fainstein, 2012). The evolution from restricted marine to open marine conditions in the late AptianAlbian interval in the Sergipe-Alagoas Basin correspond to the deposition of the sediments of the Riachuelo Formation occurring in the beginning of the drift phase (e.g., Koutsoukos et al., 1991b; Koutsoukos and Bengtson, 1993; Feijó, 1996).

The Riachuelo Formation is a $2800 \mathrm{~m}$ thick sedimentary package belonging to the Sergipe Group (Fig. 3). It is mainly characterized by mixed calcareous and siliciclastic sediments deposited in a shelf setting (e.g., Schaller, 1969; Cainelli et al., 1987; Koutsoukos and Bengtson, 1993; Campos Neto et al., 2007). The biota of this unit is mainly composed of ammonites, calcareous nannofossils, foraminifers, ostracods, dinoflagellates, gastropods, bivalves, and echinoids (e.g., Schaller, 1969; Koutsoukos, 1989; Antonietto et al., 2015; Bengtson et al., 2018). The unit was assigned to the Lower Cretaceous (upper Aptian-Albian interval) mainly based on the ammonite biozones (Schaller, 1969; Bengtson et al., 2018). The Riachuelo Formation is subdivided, from base to top, into the Angico, Maruim, and Taquari members (Fig. 3). The deposits of the Angico Member are located mainly on the edge of the basin and in lowered blocks. It represents delta fan deposits composed of mixed calcareoussiliciclastic sediments. The Maruim Member reflects areas that had a lower sedimentary input, and it is composed of grainstones and oolitic/oncolitic packstones deposited on a carbonate shelf. Finally, the Taquari Member represents the deposition of mudstones and wackestones in lagoons on the external shelf and on the slope (e.g., Schaller, 1969; Cainelli et al., 1987; Campos Neto et al., 2007). The goal of our work is the development of a high-resolution multiproxy study (microfossils, macrofossils, ichnofossils, sedimentological, geochemical, and paleomagnetic data) using cores of the Riachuelo Formation to contribute to the understanding of the impact of establishing gateways in the formation of the South Atlantic, the composition of the marine biota in the South Atlantic Ocean, possible correlation with the Tethyan realm biota or determination of endemism for the assemblages, and the recognition of global paleoclimatic and paleoceanographic events in the Sergipe-Alagoas Basin.

\section{Drilling operations and sampling}

The drilling campaigns (Table 1) started in August 2014 and were successfully completed in April 2015, but investigations on the core were not begun before the year 2019. The drilling was in the onshore section of the Sergipe-Alagoas Basin (Sergipe sub-basin) because the paleoenvironmental changes were more conspicuous in the onshore section of the unit, where the sedimentary deposits contain a diverse, abundant, and well-preserved marine macro- and microfossil assemblage (e.g., Manso and Souza-Lima, 2003; Hessel, 2004; Bengtson et al., 2018). Also, marine microfossils (mainly foraminifera) were present and have been considered a useful tool for understanding the paleoenvironmental evolution of the basin (Koutsoukos, 1989; Antonietto et al., 2015). The drill sites were located mainly in quarries close to outcrops with paleontological studies (Table 1 and Fig. 2) previously assigned to the Riachuelo Formation (Aptian-Albian interval). The drilling rig was oriented mainly perpendicular to the bedding or structural orientation of the lithological units on the ground. Several precautions were taken during the drilling project to preserve the original rock chemistry: (i) only lake water was used as drilling mud; (ii) a clean drilling rig was used, which was repeatedly washed, and the drilling site was kept clean of potential contaminants; and (iii) cores were packed in plastic boxes with polyfoam chips for transportation. The project comprised the drilling of approximately $200 \mathrm{~m}$ of rock per site with a minimum of $80 \%$ recovery (Table 1 ) using a core drilling rig machine with $3.02 \mathrm{~m}$ long rods and a $50 \mathrm{~mm}$ diameter diamond drill (Fig. 4).

In total, four cores were obtained during the campaigns. Three of them (SER-01, SER-03, and SER-04) were drilled between the towns of Pacatuba, Laranjeiras, and Riachuelo, respectively (Table 1), and SER-02 was drilled in the rural area of the Siriri municipality (Fig. 2). The cores are curated at ambient room temperature at the Instituto Tecnológico de Paleoceanografia e Mudanças Climáticas (itt Oceaneon) of the Unisinos University, Brazil. This study includes the lithostratigraphic results of the SER-01, SER-03, and SER04 cores as well as the paleomagnetic data of the SER-03 core (Table 1). Technical problems during the drilling operation prevented SER-01 from reaching the desired depth of $200 \mathrm{~m}$, but the $174.7 \mathrm{~m}$ depth reached was considered satisfactory (Table 1). After core opening and initial lithologic description and fossil registration, the preliminary results were used to divide the section into distinct units (Fig. 5).

For paleomagnetic analyses, $2 \mathrm{~cm}$ thick slices were collected at a resolution of approximately $25 \mathrm{~cm}$ throughout core SER-03. Cubic samples $(2 \mathrm{~cm} \times 2 \mathrm{~cm} \times 2 \mathrm{~cm})$ were cut from the center of the slices, and the top and bottom of 


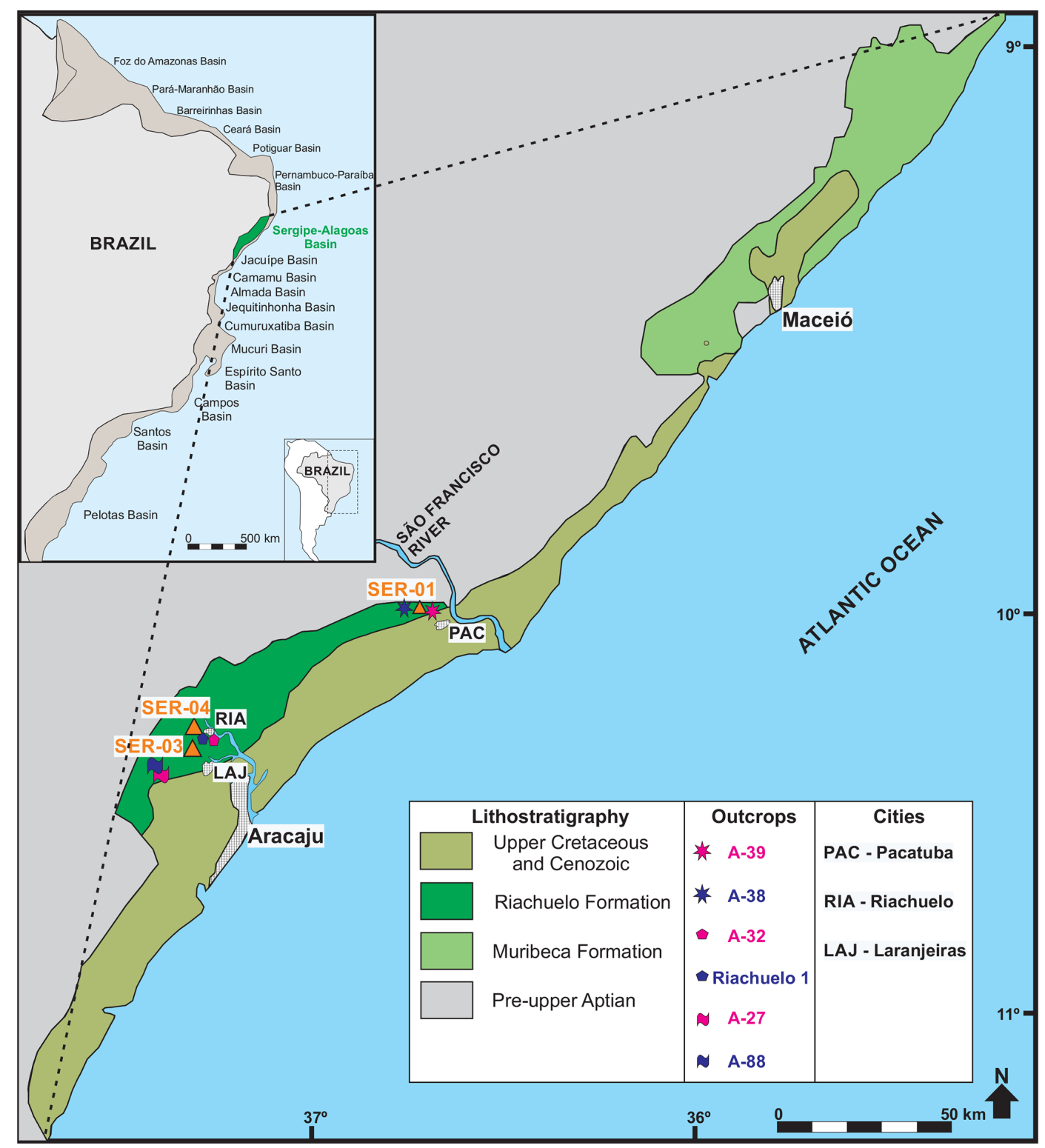

Figure 2. Sketch map of eastern Brazil with the lithostratigraphy of the Sergipe-Alagoas Basin (modified of Bengtson, 1983), locations of boreholes (SER-01, SER-03, and SER-04), key outcrops near the cores (see Table 1), and major cities.

each sample was identified. The mass of all samples was measured to normalize their mass according to magnetic parameters. Paleomagnetic susceptibility measurements were carried out at the Laboratório de Paleomagnetismo e Geomagnetismo (USPMag) of the Universidade de São Paulo. Magnetic susceptibility $(\chi)$ measurements were made with a MFK1-FA multifunction kappabridge (Dearing et al., 1996; Hrouda and Pokorný, 2012) at two operating frequencies $\left(976\right.$ and $15616 \mathrm{~Hz}$ ) in a field of $200 \mathrm{~A} \mathrm{~m}^{-1}$. To recognize the characteristic remnant magnetization (ChRM), stepwise alternating field (AF) demagnetization was used. A total of 368 samples from core SER-03 were measured after progressive AF treatment at 2, 4, 7, 10, 15, 20, 25, 30, 35, 40, 50, 60,
70, 80, 90, and $100 \mathrm{mT}$ using a $2-\mathrm{G}$ Enterprises cryogenic magnetometer (model u-channel 755R) housed in a magnetically shielded room. The components of ChRM directions were determined from the interpretation of vector end-point demagnetization diagrams (Zijderveld, 1967), and magnetic components were calculated using principal component analysis (Kirschvink, 1980) and analyzed using the Remasoft 3.0 paleomagnetic software package.

\section{Results}

The drilling campaigns managed to successfully collect Lower Cretaceous carbonate and siliciclastic sediments (on- 


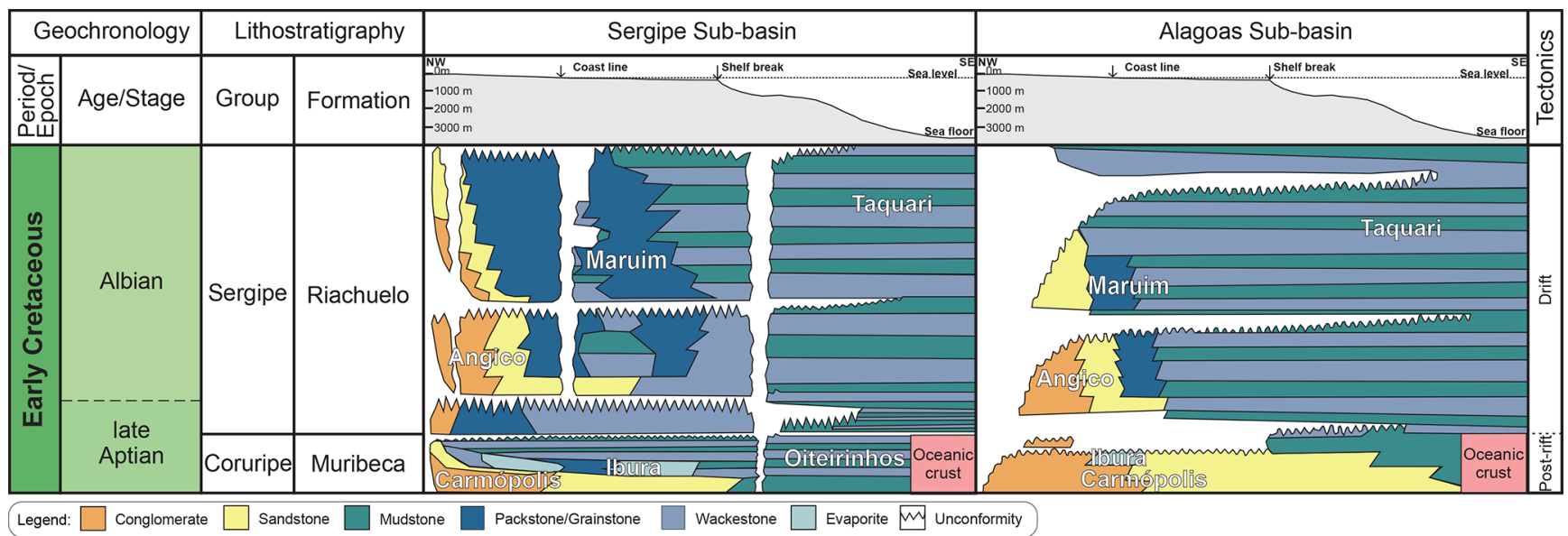

Figure 3. Lithostratigraphic chart of the late Aptian-Albian interval deposits of the Sergipe-Alagoas Basin (e.g., Schaller, 1969; Campos Neto et al., 2007; Bengtson et al., 2018).

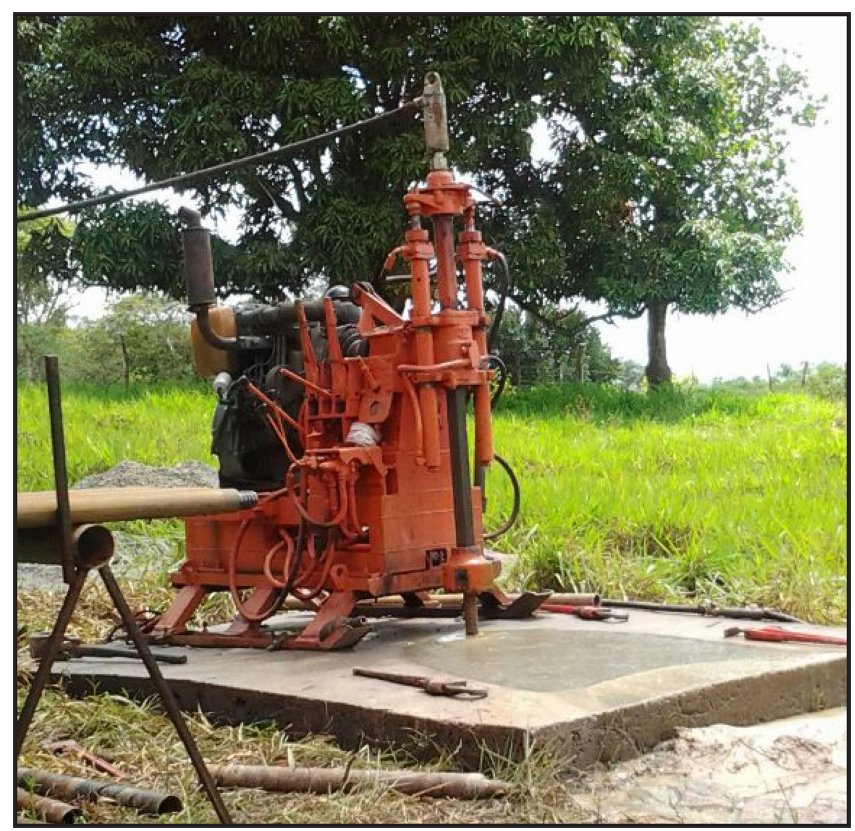

Figure 4. The drilling rig used to retrieve core material for this study was mainly oriented perpendicular to the strata truncated.

shore section) from the Riachuelo Formation, SergipeAlagoas Basin. Preliminary sedimentological results for each core that mainly represent Riachuelo Formation deposits and magnetostratigraphic, cyclostratigraphic, and biostratigraphic results of core SER-03 are summarized below (Table 1). Detailed stratigraphic studies will be carried out as more analyses of the recovered cores are performed.

Core SER-01 has a total length of $174.7 \mathrm{~m}$, with a recovery of $82.8 \%$ (Table 1). It has been divided into three main lithostratigraphic units, from the base to the top (Fig. 5). Unit I (basal unit) consists of the interval ranging from 174.7 to $99.2 \mathrm{~m}$ and is characterized mainly by fine- to coarsegrained sandstone. At the top of this unit, the sandstone is interbedded with centimeter-scale mudstone layers. In addition, within the unit, a large amount of (millimeter- to centimeter-scale) phytoclasts was observed. Unit II (99.2$24.1 \mathrm{~m}$ ) is the most calcareous interval in the section, characterized from the base to the top by light gray fine-grained sandstones, medium gray mudstones, and light gray marls (Fig. 6). Centimeter-scale beds of medium gray wackestone and packstone were observed in the interval between 81.7 and $52.4 \mathrm{~m}$, which usually contain abundant gastropod and bivalve shells as well as ooliths. In addition, small fractures filled with calcite were also observed. Unit III (24.1-2.6 m) consists mainly of medium gray shale $(24.1-14.7 \mathrm{~m})$ grading into a gray claystone (interval $14.7-2.6 \mathrm{~m}$ ). The interval between 2.6 and $0 \mathrm{~m}$ is composed of yellow to white soil and weathered rock. Outcrops (A-38 and A-39) near the core SER-01 contain late Aptian ammonites and foraminifers from the Taquari and Maruim members (Table 1).

Core SER-03 has a total length of $200.1 \mathrm{~m}$, with a recovery of $87.7 \%$ (Table 1). It was divided into two lithostratigraphic units (Fig. 5). Unit I includes the interval between 198 and $95.3 \mathrm{~m}$ and is composed mainly of thick intercalated layers of dark gray shale and light gray marl. There are at least two intervals where the shale exhibits a dark gray color (184.3-183.3 and 153.0-151.5 m). Phytoclasts occur in the shales locally. Small beds of calcareous mudstone occur between the depths of 178.3 and $177.6 \mathrm{~m}$ (Fig. 6). Ammonite shells are observed at 116.4 and $144.5 \mathrm{~m}$ (Fig. 5). Unit II $(95.3-5.8 \mathrm{~m})$ is characterized mainly by thick intercalated layers of medium light gray mudstone and medium light gray shale $(95.3-15.6 \mathrm{~m})$ followed by grayish-brown claystones $(12.5-5.8 \mathrm{~m})$. Fine- to mediumgrained sandstones forming millimeter- to centimeter-thick layers (55.2-25.7 m) can be observed at specific depths in the core. Ammonite fossils are also found in the mudstone layers 


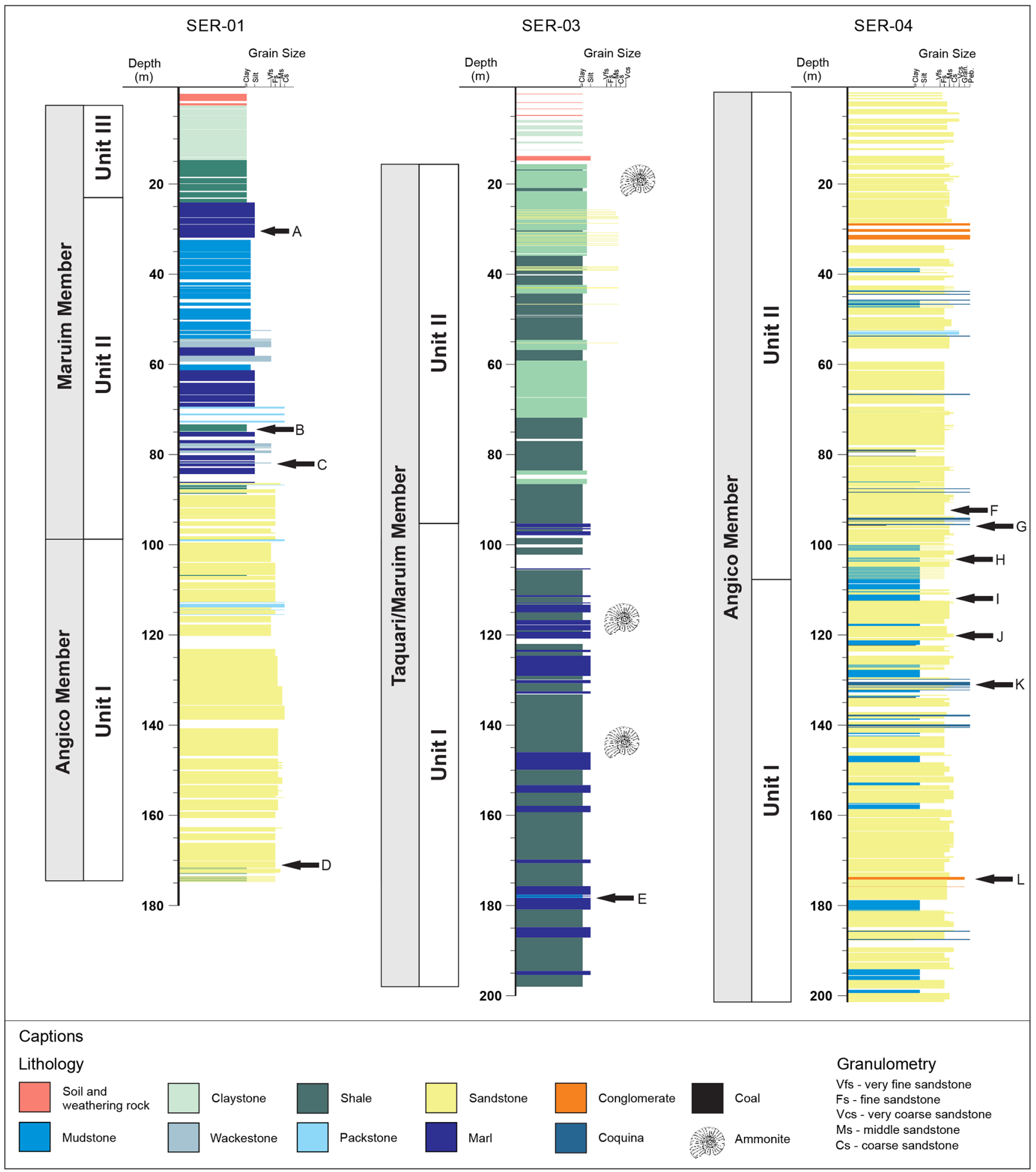

Figure 5. Stratigraphic sections of the Early Cretaceous cores (Aptian-Albian interval) from the Riachuelo Formation (Sergipe-Alagoas Basin), showing the distinct lithostratigraphic units and ammonites identified for each core. The lithostratigraphic units in each core are tentatively assigned to the different members identified in the deposits from the Riachuelo Formation. The levels (black arrows) at which detail pictures of different lithologies were taken are indicated (see Fig. 6). 
Table 1. Overview of the cores obtained from the Riachuelo Formation and Sergipe-Alagoas Basin as well as a summary of the main paleontological and stratigraphic features of outcrops in the vicinity of drill sites in the Riachuelo Formation and Sergipe-Alagoas Basin. Information adapted from Koutsoukos (1989) and Siqueira (2005).

\begin{tabular}{|c|c|c|c|}
\hline \multicolumn{4}{|l|}{ Drilled cores' data } \\
\hline Drilling data & SER-01 & SER-03 & SER-04 \\
\hline Drilling site city & Pacatuba & Laranjeiras & Riachuelo \\
\hline UTM-N (datum WGS 84) & 8848772 & 8807705 & 8812502 \\
\hline UTM-E (datum WGS 84) & 751401 & 691528 & 697149 \\
\hline Total drill core length (meters) & 174.7 & 200.1 & 201.4 \\
\hline Total recovery $(\%)$ & 82.8 & 87.7 & 82.5 \\
\hline \multicolumn{4}{|c|}{ Main paleontological and stratigraphic features of outcrops in the vicinity of drilled cores } \\
\hline Locality data & SER-01 & SER-03 & SER-04 \\
\hline Locality name & A-38 & A-27 & A-32 \\
\hline Type & $\begin{array}{l}\text { Outcrop on the road from } \\
\text { Japoatã to Pacatuba }\end{array}$ & $\begin{array}{l}\text { Outcrop on the BR-235 } \\
\text { highway }\end{array}$ & Outcrop near Riachuelo \\
\hline UTM-N (datum WGS 84) & 8849775 & 8806125 & 8812575 \\
\hline UTM-E (datum WGS 84) & 750675 & 688470 & 698525 \\
\hline Fossils & Ammonites and foraminifers & Ammonites and foraminifers & Ammonites and foraminifers \\
\hline Lithostratigraphy & $\begin{array}{l}\text { Riachuelo Formation, Taquari } \\
\text { Member }\end{array}$ & $\begin{array}{l}\text { Riachuelo Formation, Angico } \\
\text { Member }\end{array}$ & $\begin{array}{l}\text { Riachuelo Formation, Taquari } \\
\text { Member }\end{array}$ \\
\hline Biostratigraphy & $\begin{array}{l}\text { Cheloniceras spp. zone } \\
\text { (ammonite) }\end{array}$ & $\begin{array}{l}\text { Douvilleiceras euzebioi/ } \\
\text { Oxytropidoceras buarquianum } \\
\text { zones (ammonites) }\end{array}$ & $\begin{array}{l}\text { Douvilleiceras euzebioi zone } \\
\text { (ammonite) }\end{array}$ \\
\hline Age & Late Aptian & Early-middle Albian & Early Albian \\
\hline Locality data & SER-01 & SER-03 & SER-04 \\
\hline Locality name & A-39 & A-28 & Riachuelo 1 \\
\hline Type & $\begin{array}{l}\text { Santo Antônio quarry; road } \\
\text { from Japoatã to Pacatuba }\end{array}$ & $\begin{array}{l}\text { Outcrop on the BR-235 } \\
\text { highway }\end{array}$ & $\begin{array}{l}\text { Outcrop located between the } \\
\text { SE- } 210 \text { and SE-102 highways }\end{array}$ \\
\hline UTM-N (datum WGS 84) & 8847700 & 8806575 & 8812424 \\
\hline UTM-E (datum WGS 84) & 752250 & 688100 & 698482 \\
\hline Fossils & Ammonites & Ammonites & $\begin{array}{l}\text { Ammonites, bivalves (Neithea and } \\
\text { Pina), gastropods, and echinoids }\end{array}$ \\
\hline Lithostratigraphy & $\begin{array}{l}\text { Riachuelo Formation, Maruim } \\
\text { Member }\end{array}$ & $\begin{array}{l}\text { Riachuelo Formation, Angico } \\
\text { Member }\end{array}$ & Riachuelo Formation \\
\hline Biostratigraphy & $\begin{array}{l}\text { Cheloniceras spp. zone } \\
\text { (ammonite) }\end{array}$ & $\begin{array}{l}\text { Douvilleiceras euzebioi/ } \\
\text { Oxytropidoceras buarquianum } \\
\text { zones (ammonites) }\end{array}$ & $\begin{array}{l}\text { Eodouvilleiceras } \mathrm{sp} .1 \text { and } \\
\text { Douvilleiceras aff. mammillatum } \\
\text { (ammonites association) }\end{array}$ \\
\hline Age & Late Aptian & Early-middle Albian & Aptian-Albian \\
\hline
\end{tabular}

(19.5-17.5 m) (Fig. 5). Vegetation fragments occur throughout the interval. Lastly, the top $15 \mathrm{~m}$ of the core is characterized by unconsolidated soil and weathered rock. In addition, foraminifers collected from some samples were previously assigned to the Microhedbergella renilaevis and Ticinella primula planktic foraminiferal zones, suggesting an early $\mathrm{Al}-$ bian age (Kochhann et al., 2019). Outcrops (A-27 and A-28 of the Angico Member) near core SER-03 contain ammonites and foraminifers from the early-middle Albian (Table 1). 


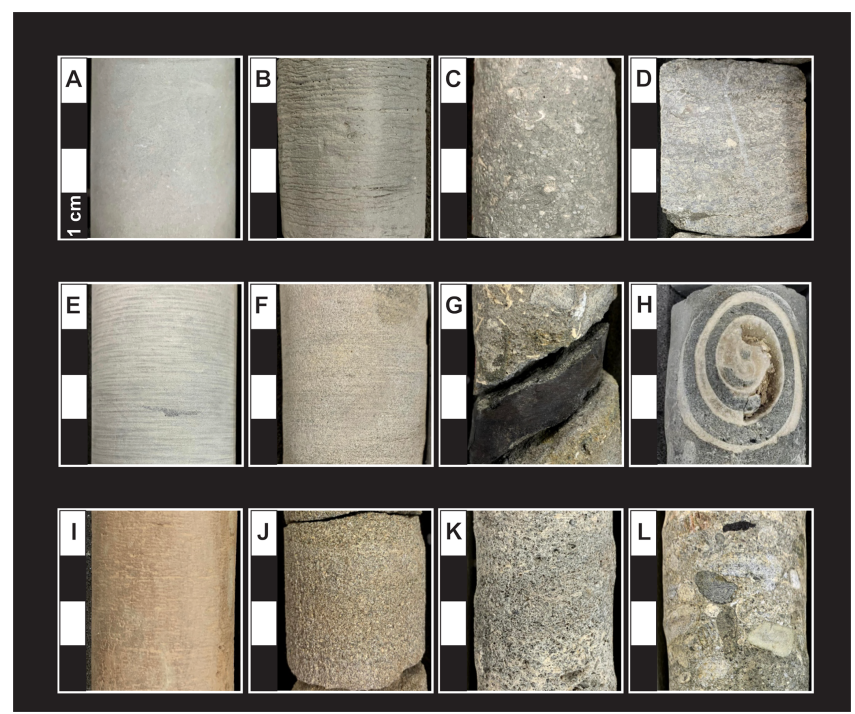

Figure 6. Core sections showing lithologies identified in this study: (A) marl (SER-01, 30.68-30.74 m); (B) shale (SER-01, 73.99$73.93 \mathrm{~m}$ ); (C) wackestone (SER-01, 81.75-81.69 m); (D) packstone (SER-01, 172.69-172.63 m); (E) mudstone (SER-03, 178.30$178.24 \mathrm{~m}$ ); (F) medium sandstone (SER-04, 93.06-93.00 m); (G) coal (SER-04, 95.63-95.62 m); (H) gastropod shell (SER04, 102.98-102.93 m); (I) mudstone (SER-04, 111.84-111.90 m); (J) coarse sandstone (SER-04, 120.85-120.79 m); (K) coquina (SER-04, 130.94-130.88 m); and (L) conglomerate (SER-04, 175.9-175.8 m). The scale bar represents $1 \mathrm{~cm}$.

Core SER-04 has a total length of $201.4 \mathrm{~m}$, with a recovery of $82.5 \%$ (Table 1). The deposits of core SER-04 are primarily sandstones with varying grain sizes. It has been divided into two main lithostratigraphic units (Fig. 5). Unit I (201.4$107.7 \mathrm{~m}$ ) is dominated by intercalated coarse- to fine-grained sandstones and thick mudstone layers (Fig. 6). Throughout the unit, there are at least eight medium reddish-brown mudstone horizons contrasted with medium light gray mudstones. There are occurrences of conglomeratic sandstone beds (two) in the interval between 175.9 and $173.8 \mathrm{~m}$ and centimeter-scale coquina beds in the interval ranging from 140.3 to $129.7 \mathrm{~m}$ (Fig. 6). Unit II $(107.7-0.9 \mathrm{~m})$ is composed mainly of fine- to coarse-grained sandstones varying in color from grayish brown to light olive gray. At the base $(107.7-100.0 \mathrm{~m})$, the unit is mainly characterized by thick layers of fine- to medium-grained sandstones interbedded with mudstones, and gastropod shells also occur (Fig. 6). These sandstones can also be interbedded with light gray coquinas, coal (95.6-43.7 m), medium light gray shales (80.3$78.9 \mathrm{~m}$ ), medium light gray mudstones $(54.7-38.9 \mathrm{~m})$, and medium light gray packstones with abundant gastropod and bivalve shells (54.3-53.2 m). Light gray conglomeratic sandstones composed of granules and pebbles occur at the top of the section (interval 32.2-28.5 m). Finally, there are two remarkable horizons of hybrid centimeter-thick sandstones containing abundant mollusk shells at depths of 26.4-21.2 and 6.0-4.4 m (Fig. 5). Outcrops (A-32 and Riachuelo 1) near core SER-04 contain Aptian-early Albian ammonites and foraminifers and a rich assemblage of bivalves, gastropods, and echinoids from the Taquari Member (Table 1).

For paleomagnetic and cyclostratigraphic data, a total of 368 discrete $\sim 8 \mathrm{~cm}^{3}$ samples from core SER-03 are measured in low ( $\chi$ lf, Fig. 7a) and high ( $\chi$ hf, Fig. 7b) operating frequencies. Magnetic susceptibility $(\chi$ lf $)$ values ranged from $1.26 \times 10^{-7}$ to $1.83 \times 10^{-8} \mathrm{~m}^{3} \mathrm{~kg}^{-1}$ (mean of $8.41 \times 10^{-8} \mathrm{~m}^{3} \mathrm{~kg}^{-1}$ ). The $\chi$ lf values displayed sharp amplitude changes throughout the core. Magnetic susceptibility $\left(\chi \mathrm{hf}\right.$ ) varied between $1.23 \times 10^{-7}$ and $1.82 \times 10^{-8} \mathrm{~m}^{3} \mathrm{~kg}^{-1}$ (mean of $8.18 \times 10^{-8} \mathrm{~m}^{3} \mathrm{~kg}^{-1}$ ) throughout core SER-03 (Fig. 7b), which is close to what was observed with $\chi$ lf. Frequency-dependent susceptibility $(\chi \mathrm{fd}=(\chi \mathrm{lf}-\chi \mathrm{hf}) / \chi$ lf $\times 100$ ) allows for the quantification of contributions from ultra-fine superparamagnetic (SP) particles (Gewehr de Mello et al., 2020). The $\chi \mathrm{fd}$ in the studied sequence (Fig. 7c) ranged from $0 \%$ to $5.69 \%$ (2.70\% average), which indicates that the samples contain a mixture of SP and coarse grains.

Throughout the studied section, the intensity of the magnetization ranged from $2.49 \times 10^{-9}$ to $9.49 \times 10^{-8} \mathrm{Am}^{2} \mathrm{~kg}^{-1}$ (mean of $2.68 \times 10^{-8} \mathrm{Am}^{2} \mathrm{~kg}^{-1}$ ) (Fig. 7d). Stepwise AF demagnetization of the representative sediment samples $(190.05,125.79,76.38$, and $23.75 \mathrm{~m})$ revealed a stable and well-defined natural remnant magnetization (NRM) component (Fig. 8). All identified magnetization directions with negative inclinations correspond to a normal polarity field (Fig. 8). These results suggest that the studied section is part of the Cretaceous Normal Superchron (Gewehr de Mello et al., 2020). Similar results have already been reported for the region (e.g., Font et al., 2009). Furthermore, Kochhann et al. (2019) developed a cyclostratigraphic preliminary study, using biostratigraphic markers (M. renilaevis and T. primula planktic foraminiferal zones) and gamma-ray data, estimating that the sedimentary succession of SER-03 spans about 4 Myr.

\section{Future plans}

The deposits recovered from the drill cores (SER-01, SER03, and SER-04) contain complete records from the AptianAlbian interval of the South Atlantic Ocean. Detailed multidisciplinary studies are being conducted in samples from these cores in order to develop a multiproxy, high-resolution dataset, which will be composed of micropaleontologic (planktonic foraminifera, calcareous nannofossils, radiolarians, ostracods, dinoflagellate cysts, pollens, and spores), microbiofaciologic, and ichnologic (ichnofabric, ichnological suites, and ichnofacies) data. Furthermore, paleomagnetic (paleosecular variation, paleointensity, environmental magnetism), geochemical (X-ray fluorescence, XRF; X-ray diffractometry, XRD; percentage of total organic carbon, TOC; sulfur, S, and $\mathrm{CaCO}_{3}$ content; and strontium, car- 


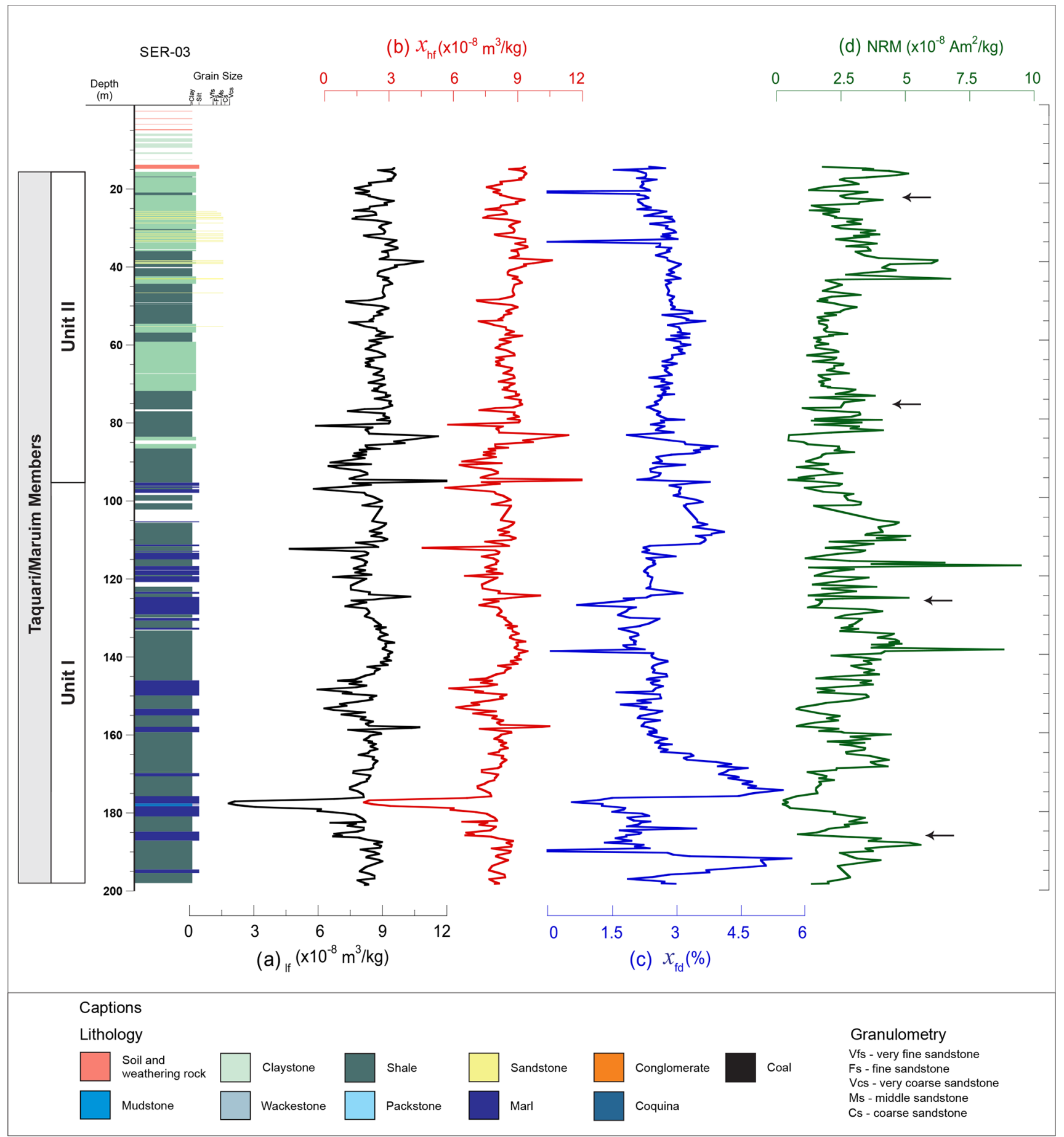

Figure 7. Magnetic susceptibility in low-frequency (a), high-frequency (b), and frequency-dependent susceptibility (c) data of 368 samples from core SER-03. Natural remnant magnetization (NRM) of 368 samples from core SER-03 is also show. The positions of the paleomagnetic samples in Fig. 8 are indicated by black arrows.

bon, oxygen, and calcium isotopes), and cyclostratigraphic (orbital tuning and evolutive spectral analysis) data will also be included. The combination of these paleontological, sedimentological, and geochemical analyses in the drill core samples will provide invaluable information about the Aptian-Albian, such as the biostratigraphy, paleoclimatic changes, paleoenvironmental evolution, and paleoceanographic parameters of the South Atlantic Ocean during this time interval. 

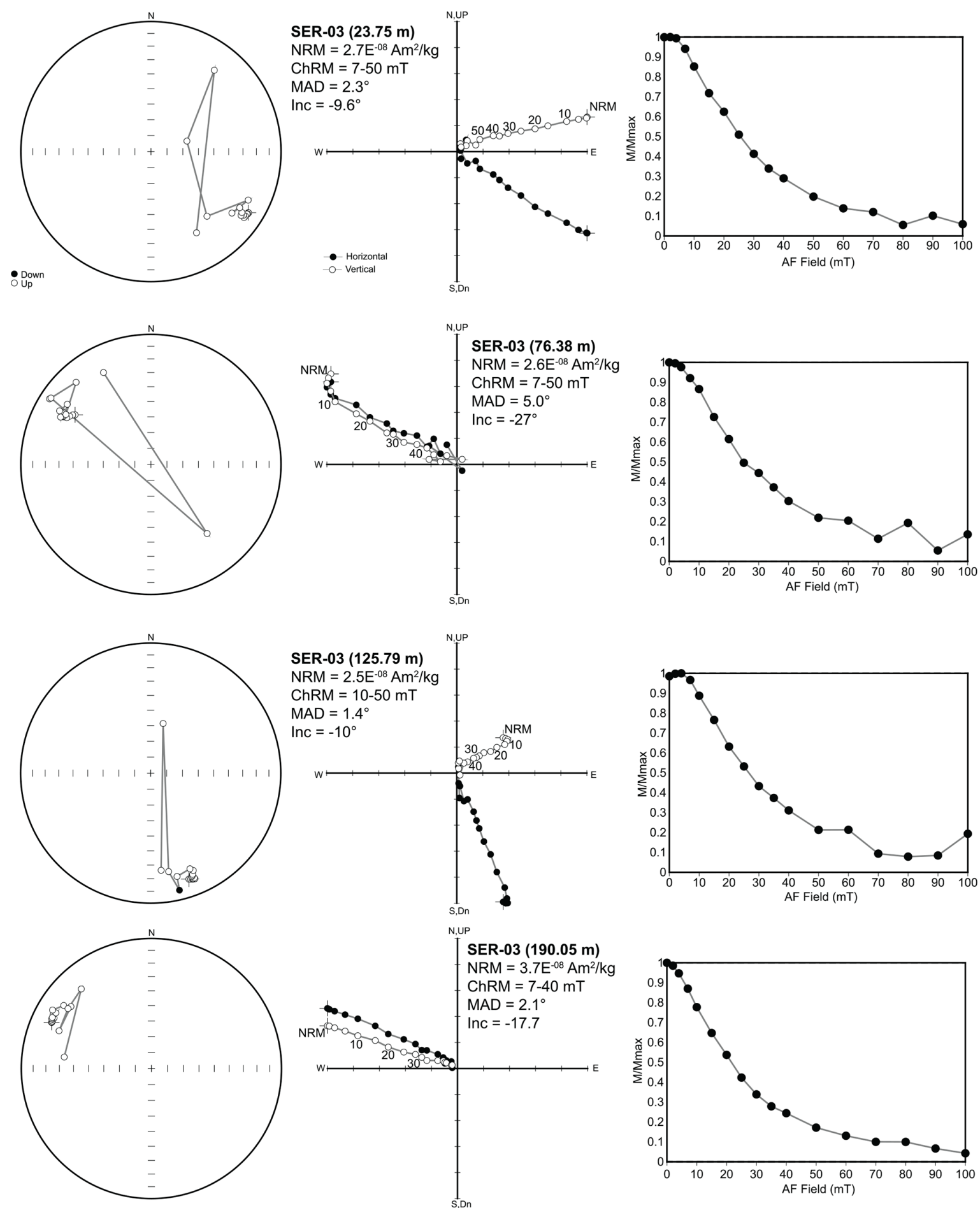

Figure 8. Typical alternating field (AF) demagnetization plots of four representative samples from the studied section. The down-core position of the samples is indicated by arrows in Fig. 7. Solid symbols indicate normal components; open symbols indicate reverse components.

\section{Conclusion}

The drilling campaigns successfully collected Lower Cretaceous rocks (onshore section) from the Riachuelo Formation of the Sergipe-Alagoas Basin. Three holes were cored in this formation; they represent the only known preserved carbonate shelf containing the Aptian-Albian transition in Brazil and most likely constitute a complete record of an AptianAlbian sedimentary section of the South Atlantic Ocean. 
Sedimentological data of the SER-01, SER-02, and SER03 cores show that mixed calcareous-siliciclastic sediments can be assigned to the Angico Member and probably represent deposits of delta fan. The calcareous rocks retrieved are part of the Maruim and Taquari members, mainly deposited on a carbonate shelf, on the external shelf, and on the slope, respectively. Furthermore, phytoclasts, gastropod, and bivalve shells were observed in the deposits of the core SER01, whereas phytoclasts, ammonite shells, and foraminifers were observed in the deposits of the core SER-03. In this core, foraminifers collected from some samples were assigned to the Microhedbergella renilaevis and Ticinella primula planktic foraminiferal zones, suggesting an early Albian age. In addition, core SER-04 recovered coquina layers and abundant mollusk shells, suggesting that microfossil assemblages can be obtained from these sediment samples. The paleomagnetic results obtained in the deposits of core SER-03 suggest that the section is part of the Cretaceous Normal Superchron. The cyclostratigraphic data and gamma-ray data suggest that the sedimentary succession spans about $4 \mathrm{Myr}$.

A combination of stratigraphic, sedimentological, paleomagnetism, geochemical, ichnological, and micropaleontological approaches will be applied to obtain critical information on the characteristics of the deposits and to understand the influence of the paleoclimatic and paleoceanographic global events (e.g., Vocontian Basin and PLG) at the AptianAlbian interval in the South Atlantic and to assess if a correlation exists between the biotic assemblages of the South Atlantic Ocean and the Tethys Sea. In addition, such integrated analysis of the late Aptian-Albian interval will bring new insights into the stratigraphy and tectonic history of the basin as well as the onset and early evolution of the South Atlantic. Cores drilled in this project can potentially allow for the correlation and calibration of local biozones with global biozones.

The results from the onshore sites drilled in the SergipeAlagoas Basin will contribute to International Ocean Discovery Program (IODP) Expedition 388, Equatorial Atlantic Gateway: origin, evolution, and paleoenvironment of the Equatorial Atlantic Gateway (Dunkley Jones et al., 2019).

Data availability. All data from this research are published in this paper.

Author contributions. GF was responsible for writing, reviewing, and editing the paper in addition to conceptualizing and supervising the study. MDRB, JVM, and JFS contributed to writing, reviewing, and editing the paper. FHdOL and OS Jr. wrote the original draft of the paper in addition to preparing, conceptualizing, and supervising the study. RdMG, GK, RGdM, FML, CGL, and EdSA contributed to the investigation.
Competing interests. The authors declare that they have no conflict of interest.

Acknowledgements. The SER cores are an integral part of the Aptian-Albian Integrated Biostratigraphy in the Sergipe-Alagoas Basin (BIOSEAL) project. This research was financially supported by Petróleo Brasileiro S.A. - PETROBRAS and regulated by the ANP (Brazilian National Petroleum Agency). The paleomagnetic measurements of the cores were made possible through support from the FAURGS (Fundação de Apoio da Universidade Federal do Rio Grande do Sul). We are grateful for the paleomagnetic analyses, carried out by the Paleomagnetism Laboratory (USPMag) of the University of São Paulo, and for the SER cores drillings, undertaken by RW Geology and Geotechnics. We would like to thank Luigi Jovane for suggestions and help in the course of the drilling project and the staff of the Instituto Tecnológico de Paleoceanografia e Mudanças Climáticas (itt Oceaneon) at Unisinos University for their general support. The authors would also like to thank the owners of the drill sites (Fazenda Santo Antônio, Usina São José do Pinheiro, and Engenho Lyra) for kindly contributing to the project. Additionally, many thanks go to Benjamin Sames and Sietske Batenburg who improved the paper with many suggestions and helpful comments and to the editor Ulrich Harms for his considerable editorial effort. Finally, we are grateful to Marcos Antonio Batista Santos Filho and Adiël A. Klompmaker for the revision of the English.

Financial support. This research has been supported by the Petróleo Brasileiro S.A. - PETROBRAS (grant nos. 5900.0110030.18.9, 0050.006930311-9, 5850.0105805.17.9).

Review statement. This paper was edited by Ulrich Harms and reviewed by Benjamin Sames and Sietske Batenburg.

\section{References}

Antonietto, L. S., Carmo, D. A., Viviers, M. C., and Adôrno, R. R.: Biostratigraphic and paleozoogeographic review of the upper Aptian-Albian ostracods of riachuelo formation, SergipeAlagoas Basin, Northeastern Brazil, Rev. Bras. Paleontolog., 18, 355-368, https://doi.org/10.4072/rbp.2015.3.02, 2015.

Arai, M.: Aptian/Albian (Early Cretaceous) paleogeography of the south atlantic: A paleontological perspective, Braz. J. Geol., 44, 339-350, https://doi.org/10.5327/Z2317-4889201400020012, 2014.

Arthur, M. A. and Natland, J. H.: Carbonaceous sediments in the North and South Atlantic: The role of salinity in stable stratification of early Cretaceous basins, in: Deep Drilling Results in the Atlantic Ocean: Continental Margins and Paleoenvironment, edited by: Talwani, M., Hay, W., and Ryan, W. B. F., American Geophysical Union, Washington, USA, 375401, available at: https://agupubs.onlinelibrary.wiley.com/doi/ 10.1029/ME003p0375 (last access: 1 April 2021), 1979.

Asmus, H. E.: Geologia da margem continental brasileira, in: Geologia do Brasil, edited by Schobbenhaus, C., Campos, D. A., Derze, G. R., and Asmus, H. E., DNPM, Brasilia, 443-472, 1984. 
Asmus, H. E. and Porto, R.: Classificação das bacias sedimentares brasileiras segundo a tectônica de placas, in: Anais do XXVI Congresso Brasileiro de Geologia, Sociedade Brasileira de Geologia, October 1972, Belem, Brazil, 67-90, 1972.

Azevedo, R. L. M.: Paleoceanografia e a evolução do Atlântico Sul no Albiano, Boletim de Geociências da Petrobras, 12, 231-249, 2004.

Bengtson, P.: The Cenomanian-Coniacian of the Sergipe Basin, Brazil, Universitetsforlaget, Oslo, Norway, 1983.

Bengtson, P., Zucon, M. H., and da Conceição Santos Sobral, A.: Cretaceous ammonite zonation of the Sergipe Basin, northeastern Brazil, Cretaceous Res., 88, 111-122, https://doi.org/10.1016/j.cretres.2017.07.021, 2018.

Berggren, W. A. and Hollister, C. D.: Paleogeography, paleobiogeography and the history of circulation in the Atlantic Ocean, in: Studies in Paleo-Oceanography, edited by: Hay, W. W., Society of Economic Paleontologists and Mineralogists, Special Publications, 126-186, http://archives.datapages.com/data/sepm_ sp/SP20/Paleogeography_Paleobiogeography.htm (last access: 15 April 2020), 1974.

Beurlen, K.: A posição estratigráfica da Formação Riachuelo (Cretáceo, Sergipe), Bol. Soc. Bras. Geol., 17, 85-88, 1968.

Biggin, A. J., van Hinsbergen, D. J. J., Langereis, C. G., Straathof, G. B., and Deenen, M. H. L.: Geomagnetic secular variation in the Cretaceous Normal Superchron and in the Jurassic, Phys. Earth Planet. In., 169, 3-19, https://doi.org/10.1016/j.pepi.2008.07.004, 2008.

Bottini, C. and Erba, E.: Mid-Cretaceous paleoenvironmental changes in the western Tethys, Clim. Past, 14, 1147-1163, https://doi.org/10.5194/cp-14-1147-2018, 2018.

Bottini, C., Erba, E., Tiraboschi, D., Jenkyns, H. C., Schouten, S., and Sinninghe Damsté, J. S.: Climate variability and ocean fertility during the Aptian Stage, Clim. Past, 11, 383-402, https://doi.org/10.5194/cp-11-383-2015, 2015.

Browning, E. L. and Watkins, D. K.: Elevated primary productivity of calcareous nannoplankton associated with ocean anoxic event $1 \mathrm{~b}$ during the Aptian/Albian transition (Early Cretaceous), Paleoceanography, 23, 1-11, https://doi.org/10.1029/2007PA001413, 2008.

Bruno, M. D. R., Fauth, G., Watkins, D. K., and Savian, J. F.: Albian-Cenomanian calcareous nannofossils from DSDP Site 364 (Kwanza Basin, Angola): Biostratigraphic and paleoceanographic implications for the South Atlantic, Cretaceous Res., 109, 104377, https://doi.org/10.1016/j.cretres.2020.104377, 2020.

Cainelli, C., Babinski, N. A., Santos, R. C. R., and Uesugui, N.: Sedimentos albo-santonianos da Bacia Sergipe-Alagoas: ambientes de sedimentação e perspectivas petrolíferas, Revista Brasileira de Geociências, 17, 135-138, 1987.

Campos Neto, O. P. d. A., Souza-Lima, W., and Gomes Cruz, F. E.: Bacia de Sergipe-Alagoas, Boletim de Geociências da Petrobras, 15, 405-415, 2007.

Carvalho, M. d. A., Bengtson, P., and Lana, C. C.: Late Aptian (Cretaceous) paleoceanography of the South Atlantic Ocean inferred from dinocyst communities of the Sergipe Basin, Brazil, Paleoceanography, 31, 2-26, https://doi.org/10.1002/2014PA002772, 2016.

Clarke, L. J. and Jenkyns, H. C.: New oxygen isotope evidence for long-term Cretaceous climatic, Ge- ology, 27, 699-702, https://doi.org/10.1130/00917613(1999)027<0699:NOIEFL>2.3.CO;2, 1999.

Coccioni, R., Jovane, L., Bancalà, G., Bucci, C., Fauth, G., Frontalini, F., Janikian, L., Savian, J., Paes de Almeida, R., Mathias, G. L., and Ferreira da Trindade, R. I.: UmbriaMarche Basin, Central Italy: A Reference Section for the Aptian-Albian Interval at Low Latitudes, Sci. Dril., 13, 42-46, https://doi.org/10.2204/iodp.sd.13.07.2011, 2012.

Coccioni, R., Sabatino, N., Frontalini, F., Gardin, S., Sideri, M., and Sprovieri, M.: The neglected history of Oceanic Anoxic Event 1b: insights and new data from the Poggio le Guaine section (Umbria-Marche Basin), Stratigraphy, 11, 245-282, 2014.

Colin, J.-P. and Andreu, B.: Cretaceous halocyprid Ostracoda, in: Ostracoda and Global Events, edited by: Whatley, C. and Maybury, R., Chapman and Hall, London, UK, 515-523, 1990.

Courtillot, V. E. and Renne, P. R.: On the ages of flood basalt events, C. R. Geosci., 335, 113-140, https://doi.org/10.1016/S16310713(03)00006-3, 2003.

Cronin, M., Tauxe, L., Constable, C., Selkin, P., and Pick, T.: Noise in the quiet zone, Earth Planet. Sc. Lett., 190, 13-30, https://doi.org/10.1016/S0012-821X(01)00354-5, 2001.

Dearing, J. A., Dann, R. J. L., Hay, K., Lees, J. A., Loveland, P. J., Maher, B. A., and O'Grady, K.: Frequency-dependent susceptibility measurements of environmental materials, Geophys. J. Int., 124, 228-240, https://doi.org/10.1111/j.1365246X.1996.tb06366.x, 1996.

Dias-Brito, D.: A Bacia de Campos no MesoCretáceo: Uma contribuição à paleoceanografia do Atlântico Sul primitivo, Revista Brasileira de Geociências, 17, 162-167, https://doi.org/10.25249/0375-7536.1987162167, 1987.

Dummann, W., Steinig, S., Hofmann, P., Flögel, S., Osborne, A. H., Frank, M., Herrle, J. O., Bretschneider, L., Sheward, R. M., and Wagner, T.: The impact of Early Cretaceous gateway evolution on ocean circulation and organic carbon burial in the emerging South Atlantic and Southern Ocean basins, Earth Planet. Sc. Lett., 530, 1-11, https://doi.org/10.1016/j.eps1.2019.115890, 2020.

Dunkley Jones, T., Fauth, G., and LeVay, L. J.: Expedition 388 Scientific Prospectus: Equatorial Atlantic Gateway: origin, evolution, and paleoenvironment of the Equatorial Atlantic Gateway, International Ocean Discovery Program, 1-31, https://doi.org/10.14379/iodp.sp.388.2019, 2019.

Erbacher, J., Hemleben, C., Huber, B. T., and Markey, M.: Correlating environmental changes during early Albian oceanic anoxic event 1B using benthic foraminiferal paleoecology, Mar. Micropaleontol., 38, 7-28, https://doi.org/10.1016/S03778398(99)00036-5, 1999.

Feijó, F. J.: Bacias de Sergipe e Alagoas, Boletim de Geociências da Petrobras, 8, 149-161, 1994.

Feijó, F. J.: O início da livre circulação das águas do Oceano Atlântico, Boletim de Geociências da Petrobras, 10, 157-164, 1996.

Föllmi, K. B.: Early Cretaceous life, climate and anoxia, Cretaceous Res., 35, 230-257, https://doi.org/10.1016/j.cretres.2011.12.005, 2012.

Font, E., Ernesto, M., Silva, P. F., Correia, P. B., and Nascimento, M. A. L.: Palaeomagnetism, rock magnetism and AMS of the Cabo Magmatic Province, NE Brazil, and the opening of South Atlantic, Geophys. J. Int., 179, 905-922, https://doi.org/10.1111/j.1365-246X.2009.04333.x, 2009. 
Gale, A. S., Mutterlose, J., Batenburg, S. J., Gradstein, F. M., Agterberg, F. P., Ogg, J. G., and Petrizzo, M. R.: The Cretaceous Period, in: Geologic Time Scale 2020, edited by: Gradstein, F. M., Ogg, J. G., Schmitz, M. B., and Ogg, G. M., Elsevier, 1023-1086, https://doi.org/10.1016/C2020-1-02369-3, 2020.

Gee, J. S. and Kent, D. V.: Source of Oceanic Magnetic Anomalies and the Geomagnetic Polarity Timescale, Treatise on Geophysics, 5, 455-507, https://doi.org/10.7916/D8DV1V8P, 2007.

Gewehr de Mello, R., Fauth, G., Guilherme Diemer Kochhann, K., Gonsalves Leandro, C., Daniel Rodrigues Bruno, M., Krahl, G., Marcanth Lopes, F., and Francisco Savian, J.: Magnetostratigraphy and environmental magnetism of the Aptian-Albian boundary of sedimentary core from Sergipe-Alagoas Basin: preliminary results, EGU General Assembly 2020, Online, 4-8 May 2020, EGU2020-17533, https://doi.org/10.5194/egusphereegu2020-17533, 2020.

Granot, R., Tauxe, L., Gee, J. S., and Ron, H.: A view into the Cretaceous geomagnetic field from analysis of gabbros and submarine glasses, Earth Planet. Sc. Lett., 256, 1-11, https://doi.org/10.1016/j.epsl.2006.12.028, 2007.

Granot, R., Dyment, J., and Gallet, Y.: Geomagnetic field variability during the Cretaceous Normal Superchron, Nat. Geosci., 5, 220223, https://doi.org/10.1038/ngeo1404, 2012.

Haq, B. U.: Cretaceous eustasy revisited, Global Planet. Change, 113, 44-58, https://doi.org/10.1016/j.gloplacha.2013.12.007, 2014.

Hay, W. W., DeConto, R. M., Wold, C. N., Wilson, K. M., Voigt, S., Schulz, M., Rossby Wold, A., Dullo, W. C., Ronov, A. B., Balukhovsky, A. N., and Söding, E.: Alternative global Cretaceous paleogeography, in: Evolution of the Cretaceous Oceanclimate System, edited by: Barrera, C. C. and Johnson, E., Geological Society of America, Special Paper, Boulder, Colorado, USA, 1-47, 1999.

He, H., Pan, Y., Tauxe, L., Qin, H., and Zhu, R.: Toward age determination of the M0r (Barremian-Aptian boundary) of the Early Cretaceous, Phys. Earth Planet. In., 169, 41-48, https://doi.org/10.1016/j.pepi.2008.07.014, 2008.

Helsley, C. E. and Steiner, M. B.: Evidence for long intervals of normal polarity during Cretaceous period, Earth Planet. Sc. Lett., 1, 325-332, https://doi.org/10.1016/S0012-821X(68)80060-3, 1968.

Herrle, J. O. and Mutterlose, J.: Calcareous nannofossils from the Aptian-Lower Albian of southeast France: Palaeoecological and biostratigraphic implications, Cretaceous Res., 24, 1-22, https://doi.org/10.1016/S0195-6671(03)00023-5, 2003.

Herrle, J. O., Kößler, P., Friedrich, O., Erlenkeuser, H., and Hemleben, C.: High-resolution carbon isotope records of the Aptian to Lower Albian from SE France and the Mazagan Plateau (DSDP Site 545): A stratigraphic tool for paleoceanographic and paleobiologic reconstruction, Earth Planet. Sc. Lett., 218, 149161, https://doi.org/10.1016/S0012-821X(03)00646-0, 2004.

Herrle, J. O., Schröder-Adams, C. J., Davis, W., Pugh, A. T., Galloway, J. M., and Fath, J.: Mid-cretaceous high arctic stratigraphy, climate, and oceanic anoxic events, Geology, 43, 403-406, https://doi.org/10.1130/G36439.1, 2015.

Hessel, M. H.: Gervillia (Gervillia) solenoidea Defrance, 1820 (Bivalvia Bakevelliidae) do Neo-aptiano de Sergipe, Brasil, Rev. Bras. Paleontolog., 7, 67-76, 2004.
Hrouda, F. and Pokorný, J.: Modelling accuracy limits for frequency-dependent anisotropy of magnetic susceptibility of rocks and soils, Stud. Geophys. Geod., 56, 789-802, https://doi.org/10.1007/s11200-011-9009-5, 2012.

$\mathrm{Hu}$, X., Wagreich, M., and Yilmaz, I. O.: Marine rapid environmental/climatic change in the Cretaceous greenhouse world, Cretaceous Res., 38, 1-6, https://doi.org/10.1016/j.cretres.2012.04.012, 2012.

Huber, B. T. and Leckie, R. M.: Planktic foraminiferal species turnover across deep-sea Aptian/Albian boundary sections, J. Foramin. Res., 41, 53-95, https://doi.org/10.2113/gsjfr.41.1.53, 2011.

Huber, B. T., MacLeod, K. G., Gröcke, D. R., and Kucera, M.: Paleotemperature and paleosalinity inferences and chemostratigraphy across the Aptian/Albian boundary in the subtropical North Atlantic, Paleoceanography, 26, 1-20, https://doi.org/10.1029/2011PA002178, 2011.

Jenkyns, H. C.: Geochemistry of oceanic anoxic events, Geochem. Geophy. Geosy., 11, 1-30, https://doi.org/10.1029/2009GC002788, 2010.

Jenkyns, H. C., Schouten-Huibers, L., Schouten, S., and Sinninghe Damsté, J. S.: Warm Middle Jurassic-Early Cretaceous high-latitude sea-surface temperatures from the Southern Ocean, Clim. Past, 8, 215-226, https://doi.org/10.5194/cp-8-215-2012, 2012.

Kellogg, J. N. and Mohriak, W. U.: The Tectonic and Geological Environment of Coastal South America, in: Coastal Marine Ecosystems of Latin America, edited by: Seelinger, B. and Kjerfbe, U., 1-16, Springer, Berlin, Heidelberg, Germany, 2001.

Kennedy, J. W., Gale, A. S., Bown, P. R., Caron, M., Davey, R. J., Gröcke, D. R., and Wray, D. S.: Integrated stratigraphy across the Aptian-Albian boundary in the Marnes Bleues, at the Col de Pre-Guittard, Arnayon (Drome), and at Tartonne (Alpes-deHaute-Provence), France: A candidate global boundary stratotype section and boundary point for the base, Cretaceous Res., 21, 591-720, https://doi.org/10.1006/cres.2000.0223, 2000.

Kennedy, J. W., Gale, A. S., Huber, B. T., Petrizzo, M. R., Bown, P. R., Barchetta, A., and Jenkyns, H. C.: Integrated stratigraphy across the Aptian/Albian boundary at Col de Pré-Guittard (southeast France): A candidate global boundary stratotype section, Cretaceous Res., 51, 248-259, https://doi.org/10.1016/j.cretres.2014.06.005, 2014.

Kennedy, J. W., Gale, A. S., Huber, B. T., Petrizzo, M. R., Bown, P. R., and Jenkyns, H. C.: The Global Boundary Stratotype Section and Point (GSSP) for the base of the Albian Stage, of the Cretaceous, the Col de Pré-Guittard section, Arnayon, Drôme, France, Episodes, 40, 177-188, https://doi.org/10.18814/epiiugs/2017/v40i3/017021, 2017.

Kirschvink, J. L.: The least-square line and plane and the analysis of paleomagnetic data, Geophys. J. Roy. Astr. S., 62, 699-718, https://doi.org/10.1111/j.1365-246X.1980.tb02601.x, 1980.

Kochhann, K. G. D., Krahl, G., Fauth, G., do Monte Guerra, R., Bruno, M. D. R., da Silva Aguiar, E., and Lima, F. H. O.: Cyclostratigraphy of Early Albian Marine Strata of the Sergipe Basin, Brazil, in: AGU Fall Meeting 2019, AGU, 9-13 December 2019, San Francisco, USA, https://agu.confex.com/agu/ fm19/meetingapp.cgi/Paper/537653 (last access: 27 April 2020), 2019. 
Koutsoukos, E. A. M.: Mid- to Late Cretaceous microbiostratigraphy, palaeoecology and palaeogeography of the Sergipe basin, northeastern Brazil, PhD Thesis, Department of Geological Sciences of Polytechnic South West, Plymouth, UK, 856 pp., 1989.

Koutsoukos, E. A. M.: Late Aptian to Maastrichtian foraminiferal biogeography and palaeoceanography of the Sergipe Basin, Brazil, Palaeogeogr. Palaeocl., 92, 295-324, https://doi.org/10.1016/0031-0182(92)90089-N, 1992.

Koutsoukos, E. A. M. and Bengtson, P.: Towards an integrated biostratigraphy of the upper Aptian-Maastrichtian of the Sergipe Basin, Brazil, Documents des laboratoires de géologie, 125, 241262, 1993.

Koutsoukos, E. A. M., Mello, M. R., and Azambuja Filho, N. C.: Micropalaeontological and geochemical evidence of midCretaceous dysoxic-anoxic palaeoenvironments in the Sergipe Basin, northeastern Brazil, Geol. Soc. Spec. Publ., 58, 427-447, https://doi.org/10.1144/GSL.SP.1991.058.01.27, 1991a.

Koutsoukos, E. A. M., Mello, M. R., Azambuja Filho, N. C., Hart, M. B., and Maxwell, J. R.: The upper AptianAlbian succession of the Sergipe Basin, Brazil: an integrated paleoenvironmental assessment, AAPG Bull., 75, 479-498, https://doi.org/10.1306/0C9B2817-1710-11D78645000102C1865D, 1991b.

Leckie, R. M., Bralower, T. J., and Cashman, R.: Oceanic anoxic events and plankton evolution: Biotic response to tectonic forcing during the mid-Cretaceous, Paleoceanography, 17, 13-1-1329, https://doi.org/10.1029/2001pa000623, 2002.

Linder, J. and Gilder, S. A.: Geomagnetic secular variation recorded by sediments deposited during the Cretaceous normal superchron at low latitude, Phys. Earth Planet. In., 187, 245-260, https://doi.org/10.1016/j.pepi.2011.05.010, 2011.

Manso, C. L. C. and Souza-Lima, W.: O Equinóide Douvillaster Lambert, 1917 na Formação Riachuelo, Bacia de Sergipe, Brasil, Rev. Bras. Paleontolog., 5, 29-37, 2003.

McAnena, A., Flögel, S., Hofmann, P., Herrle, J. O., Griesand, A., Pross, J., Talbot, H. M., Rethemeyer, J., Wallmann, K., and Wagner, T.: Atlantic cooling associated with a marine biotic crisis during the mid-Cretaceous period, Nat. Geosci., 6, 558-561, https://doi.org/10.1038/NGEO1850, 2013.

Michels, F. H., de Souza, P. A., and Premaor, E.: Aptian-Albian palynologic assemblages interbedded within salt deposits in the Espírito Santo Basin, eastern Brazil: Biostratigraphical and paleoenvironmental analysis, Mar. Petrol. Geol., 91, 785-799, https://doi.org/10.1016/j.marpetgeo.2018.01.023, 2018.

Milani, E. J., Rangel, H. D., Bueno, G. V., Stica, J. M., Winter, W. R., Caixeta, J. M., and Pessoa Neto, O. d. C.: Bacias Sedimentares Brasileiras - Cartas Estratigráficas, Boletim de Geociências da Petrobras, 15, 183-205, 2007.

Mohriak, W. U.: Bacias Sedimentares da Margem Continental Brasileira, in: Geologia, Tectônica e Recursos Minerais do Brasil, edited by: Bizzi, J. H., Schobbenhaus, L. A., Vidottie, C., and Gonçalves, R. M., CPRM, Brasilia, 87-165, 2003.

Mohriak, W. U. and Fainstein, R.: Phanerozoic regional geology of the eastern Brazilian margin, in: Regional Geology and Tectonics, Elsevier, 222-282, https://doi.org/10.1016/B978-0-44456357-6.00006-8, 2012.

Mohriak, W. U., Bassetto, M., and Vieira, I. S.: Crustal architecture and tectonic evolution of the Sergipe-Alagoas and Jacuípe basins, offshore northeastern Brazil, Tectonophysics, 288, 199-220, https://doi.org/10.1016/B978-0-444-56357-6.00006-8, 1998.

Mohriak, W. U., Nemcok, M., and Enciso, G.: South Atlantic divergent margin evolution: rift-border uplift and salt tectonics in the basins of SE Brazil, in: Geological Society, edited by: Pankhurst, M. J., Trouw, R. J., Brito Neves, R. A. J., and de Wit, B. B., Geological Society, Special Publications, London, UK, 365-951, https://doi.org/10.1144/SP294.19, 2008.

Mutterlose, J., Bornemann, A., and Herrle, J. O.: The Aptian - Albian cold snap: Evidence for "mid" Cretaceous icehouse interludes, Neues Jahrb. Geol. P.-A., 252, 217-225, https://doi.org/10.1127/0077-7749/2009/0252-0217, 2009.

O’Brien, C. L., Robinson, S. A., Pancost, R. D., Sinninghe Damsté, J. S., Schouten, S., Lunt, D. J., Alsenz, H., Bornemann, A., Bottini, C., Brassell, S. C., Farnsworth, A., Forster, A., Huber, B. T., Inglis, G. N., Jenkyns, H. C., Linnert, C., Littler, K., Markwick, P., McAnena, A., Mutterlose, J., Naafs, B. D. A., Püttmann, W., Sluijs, A., van Helmond, N. A. G. M., Vellekoop, J., Wagner, T., and Wrobel, N. E.: Cretaceous sea-surface temperature evolution: Constraints from TEX86 and planktonic foraminiferal oxygen isotopes, Earth-Sci. Rev., 172, 224-247, https://doi.org/10.1016/j.earscirev.2017.07.012, 2017.

Ogg, J. G., Ogg, G. M., and Gradstein, F. M.: A concise geologic time scale 2016, Elsevier, 234 pp., 2016.

Pérez-Díaz, L. and Eagles, G.: South Atlantic paleobathymetry since early Cretaceous, Sci. Rep.-UK, 7, 1-16, https://doi.org/10.1038/s41598-017-11959-7, 2017.

Petrizzo, M. R., Huber, B. T., Gale, A. S., Barchetta, A., and Jenkyns, H. C.: Abrupt planktic foraminiferal turnover across the niveau kilian at col de pré-guittard (Vocontian Basin, southeast France): New criteria for defining the Aptian/Albian boundary, Newsl. Stratigr., 45, 55-74, https://doi.org/10.1127/00780421/2012/0013, 2012.

Petrizzo, M. R., Wagreich, M., and Haggart, J.: Annual Report 2016 of the International Subcommission on Cretaceous Stratigraphy, available at: http://cretaceous.stratigraphy.org/archives/ (last access: 10 April 2020), 2016.

Pirrie, D., Doyle, P., Marshall, J. D., and Ellis, G.: Cool Cretaceous climates: new data from the Albian of Western Australia, J. Geol. Soc. London, 152, 139-142, https://doi.org/10.1144/gsjgs.152.5.0739, 1995.

Pirrie, D., Marshall, J. D., Doyle, P., and Riccardi, A. C.: Cool early Albian climates, new data from Argentina, Cretaceous Res., 25, 27-33, https://doi.org/10.1016/j.cretres.2003.10.002, 2004.

Rabinowitz, P. D. and Labrecque, J.: The Mesozoic South Atlantic Ocean and Evolution of Its Continental Margins, J. Geophys. Res.-Sol. Ea., 84, 5973-6002, https://doi.org/10.1029/JB084iB11p05973, 1979.

Rand, H. M. and Mabesoone, J. M.: Northeastern Brazil and the final separation of South America and Africa, Palaeogeogr. Palaeocl., 38, 163-183, https://doi.org/10.1016/00310182(82)90002-5, 1982.

Riccardi, A. C.: Jurassic and Cretaceous marine connections between the Southeast Pacific and Tethys, Palaeogeogr. Palaeocl., 87, 189, https://doi.org/10.1016/0031-0182(91)90134-D, 1991.

Sabatino, N., Coccioni, R., Salvagio Manta, D., Baudin, F., Vallefuoco, M., Traina, A., and Sprovieri, M.: High-resolution chemostratigraphy of the late Aptian-early Albian oceanic anoxic event (OAE 1b) from the Poggio le Guaine section 
(Umbria-Marche Basin, central Italy), Palaeogeogr. Palaeocl., 426, 319-333, https://doi.org/10.1016/j.palaeo.2015.03.009, 2015.

Sabatino, N., Ferraro, S., Coccioni, R., Bonsignore, M., del Core, M., Tancredi, V., and Sprovieri, M.: Mercury anomalies in upper Aptian-lower Albian sediments from the Tethys realm, Palaeogeogr. Palaeocl., 495, 163-170, https://doi.org/10.1016/j.palaeo.2018.01.008, 2018.

Satolli, S., Besse, J., Speranza, F., and Calamita, F.: The 125150 Ma high-resolution Apparent Polar Wander Path for Adria from magnetostratigraphic sections in Umbria-Marche (Northern Apennines, Italy): Timing and duration of the global JurassicCretaceous hairpin turn, Earth Planet. Sc. Lett., 257, 329-342, https://doi.org/10.1016/j.epsl.2007.03.009, 2008.

Schaller, H.: Revisão estratigráfica da Bacia de Sergipe/Alagoas, Boletim Técnico da Petrobras, 12, 21-86, 1969.

Sibuet, J.-C., Hay, W. W., Prunier, A., Montadert, L., Hinz, K., and Fritsch, J.: Early evolution of the South Atlantic Ocean: role of the rifting episode, in: Initial Reports of the Deep Sea Drilling Project, edited by: Hay, J. C. and Sibuet, W. H., U.S. Government Printing Office, Washington, USA, 469-481, https://doi.org/10.2973/dsdp.proc.75.107.1984, 1984.

Silva Jr., R., de Moraes Rios-Netto, A., Silva, S. C., Valle, B., Borghi, L., and Abbots-Queiroz, F.: Middle Cretaceous calcareous nannofossils from the cored well UFRJ-2-LRJ01-SE, Sergipe-Alagoas Basin, Brazil: New biostratigraphy and paleobiogeographic inferences, Cretaceous Res., 106, https://doi.org/10.1016/j.cretres.2019.104245, 2020.
Siqueira, M. H. Z. R.: Amonóides da transição Aptiano-Albiano da Bacia de Sergipe, Brasil, PhD Thesis, Universidade Federal da Bahia, Salvador, 165 pp., 2005.

Tarduno, J. A.: Brief reversed polarity interval during the Cretaceous Normal Polarity Superchron, Geology, 18, 683-686, https://doi.org/10.1130/00917613(1990)018<0683:BRPIDT>2.3.CO;2, 1990.

Tarduno, J. A., Cottrell, R. D., and Smirnov, A. V.: High Geomagnetic Intensity during the Mid-Cretaceous from Thellier analyses of single plagioclase crystals, Science, 291, 1779-1783, https://doi.org/10.1126/science.1057519, 2001.

Torsvik, T. H., Rousse, S., Labails, C., and Smethurst, M. A.: A new scheme for the opening of the South Atlantic Ocean and the dissection of an Aptian salt basin, Geophys. J. Int., 177, 13151333, https://doi.org/10.1111/j.1365-246X.2009.04137.x, 2009.

Valle, B., Dal'Bó, P. F. F., Mendes, M., Favoreto, J., Rigueti, A. L., Borghi, L., and Silva, R.: Stratigraphic evolution of a Brazilian carbonate platform during the Cretaceous: the late Albianearly Turonian of the Sergipe-Alagoas Basin, Facies, 65, 1-17, https://doi.org/10.1007/s10347-018-0543-2, 2019.

Zijderveld, J. D. A.: AC demagnetization of rocks: Analysis of results, in: Methods in Palaeomagnetism, edited by: Runcorn, S. K., Creer, K. M., and Collinson, D. W., Elsevier, New York, USA, 254-286, 1967. 